DOI: https://doi.org/10.18524/2519-2523.2021.16.245742

УДК 93/94(929.5)+364.054.3

\title{
CHARITABLE ACTIVITY OF LYUBOVE IVANOVNA KURIS (1852-1935)
}

\section{Valery Kondratiuk}

Director of the Charitable Foundation named after I. Kuris

Post-graduate student of the

Odesa I. I. Mechnikov National

University 2, Dvoryanska Str., Odesa,

65082, Ukraine

ORCID: https://orcid.org/0000-0002-

7111-5142

E-mail: alla.lavrusenko@gmail.com

Citation: Kondratiuk, V. (2021) Charitable activity of Lyubove Ivanovna Kuris (18521935). Chornomors 'ka mynuvshyna, vol. 16, pp. 80-89.

Submitted: 16.11 .2021

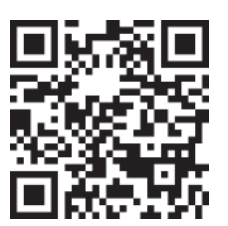

\section{Annotation}

The article examines the life and charitable activities of the famous Kuris family representative in the South of Ukraine - Lyubov Ivanovna Kuris. Based on the primary sources study, archival documentation and publications of the Lyubov I. Kuris' life period, Lybov Ivanivna's activity in Odesa region charitable societies, in her own noble estate in her homeland and in Kurisovo-Pokrovsky is covered.

Particular attention is paid to Kuris family charity tracing and continuing charitable work from generation to generation. Research of the charitable activity basis and types in the south of Ukraine.

It is established that Lyubov I. Kuris continued to carry out charitable activities after her husband's mother, Lyubov Stanislavivna Kuris, who worked fruitfully for the benefit of the Odessa Women's Charitable Society until her death.

Among the Lyubov Ivanovna main merits is the construction and maintenance of educational institutions, churches, patronage, assistance to sick children and the needy. Lyubov Ivanivna Kuris was fascinated by the idea of public education spreading. As a trustee of Kurisovo-Pokrovsky, she did a lot for the village school and school garden. In 1862, her father Ivan Alexandrovich Gizhitsky founded the first local school in Ryasnopil, which he maintained at his own expense until 1869. Later, Lyubov I. Kuris tried to continue his work.

However, the greatest cause in the field of charity Lyubov I. Kuris was her participation in the work of the Odessa Society for the Sick Children Care. She devoted almost 30 years of her life to this activity, having done many good deeds and invested in it her Christian love, charity and unquenchable energy.

Lyubov I. Kuris' activity as the chairman of the society allowed to establish contacts and involve many famous and influential people of the city. The main achievement of the Society was the medical station for children and a children's kitchen "Drop of Milk" construction. By 1901, more than 1,500 children had undergone a treatment full course at the sanitary station. Lyubov I. Kuris was also a member of the Odessa Society of History and Antiquities, was a philanthropist, passing part of her husband's collection, antique exhibits, the museum for the benefit of society.

Key words: Lyubov Ivanivna Kuris, nobility, charity, charitable societies.

\section{БЛАГОДІЙНА ДІЯЛЬНІСТЬ ЛЮБОВІ ІВАНІВНИ КУРІС (1852-1935 рр.)}

\section{Валерій Кондратюк}

Аспірант кафедри історії України Одеський національний університет імені І. І. Мечникова

Вул. Дворянська, 2, м. Одеса, 65025, Україна

Директор Благодійного фонду імені I. Kуріса

\section{Анотація}

У статті розглядається життєвий шлях та благодійна діяльність представниці славнозвісної сім'ї Курісів на півдні України - Любові Іванівни Куріс. На основі вивчення першоджерел, архівної документачії та публікаиій періоду життя Л. I. Куріс, висвітлюється діяльність Любові Іванівни в благодійних то- 
ORCID: https://orcid.org/0000$\underline{0002-7111-5142}$

E-mail: alla.lavrusenko@gmail.com

Цитування: Кондратюк В.

Благодійна діяльність Любові Іванівни Куріс (1852-1935 рр.).

Чорноморська минувшина: записки Відділу історії козацтва на півдні України: зб. наук. пр. / за. ред.

В. А. Смолія. Одеса: ФОП Бондаренко М.О., 2021. Вип. 16. С. 80-89.

Отримано: 16.11.2021 p. вариствах Одещини, у власному дворянському маєтку на ї батьківщині та в Курісово-Покровському.

Особливу увагу приділено простеженню приємства благодійниитва в родині Курісів та продовження благочинних справ від покоління до покоління. Досліджено підстави та види благодійної діяльності на півдні Украӥни.

Встановлено, щзо Любов Іванівна Куріс продовжила здійснювати благочинну діяльність після матері свого чоловіка, Любові Станіславівни Куріс, яка плідно трудилася на благо Одеського жіночого благодійного товариства, аж до часів своєї смерті.

Серед основних заслуг Любові Іванівни будівництво та утримання освітніх закладів, иерков, меценатство, допомога хворим дітям та знедоленим. Любов Іванівна

Куріс була захоплена ідеєю поширення народної освіти. Як попечителька КурісовоПокровського вона зробила чимало для сільської школи та шкільного саду. В 1862 р. її батько Іван Олександрович Гіжицький заснував у Ряснопіллі першу місцеву школу, яку утримував своїм коштом до 1869 р. Надалі його справу намагалася продовжити Л. I. Куріс.

Проте найбільшою справою на ниві благодійництва Л. І. Куріс була ї̈ участь у роботі Товариства опіки над хворими дітьми міста Одеса. Цій діяльності вона присвятила майже 30 років свого життя, зробивши безліч добрих справ і вклавши у неї свою християнську любов, милосердя і незгасиму енергію. Активність Л. І. Куріс на посаді голови Товариства дозволила налагодити контакти й залучити до справи багатьох відомих $і$ впливових людей міста. Основними досягненням Товариства стало будування лікувальної станції для дітей та дитячої кухні «Крапля молока». До 1901 р. на санітарній станції повноцінний курс лікування пройшли понад 1500 дітей. Л. І. Куріс також була й членом Одеського товариства історії та старожитностей, виступала меценатом, передавщи частину колекиї свого чоловіка, античні експонати, музею на користь суспільства.

Ключові слова: Любов Іванівна Куріс, дворянство, благодійність, благодійні товариства.

Історичний розвиток благодійності на півдні України у XIX ст. яскраво демонструє приклади людської допомоги та опіки незахищеним верствам населення. Сучасні науковці серед причин поширення благодійної діяльності у цей історичний період називають формування довіри до діючої влади та нобілітету, зниження суспільної напруженості, власні патріотичні та благодійні мотиви, соціальну відповідальність тощо.

Розвиток благодійності на півдні України, особливо на Одещині, пройшов декілька етапів i трансформаційних перетворень від приватної благодійної діяльності до законодавчого врегулювання й зміщення акцентів в бік територіальних громад та муніципалітету. Незважаючи на вказане, благодійність була в основному властива тільки одній верстві населення - дворянству. Не дивно, адже саме вона виховувалась у повазі та відданості державі і суспільству.

Благодійність здійснювалась за різними напрямами - від пожертвувань на війну і для військових, до будування навчальних закладів та церков. Важлива роль у цій діяльності відводилась саме жінкам. Почесним вважалося власна поміч та допомога хворим, безпритульним, знедоленим.

Родина Курісів на півдні України, їі відомі представники, здійснили чимало для служіння державі та суспільству. Невисвітленою в вітчизняних дослідженнях залишається життєвих шлях та культурно-соціальна діяльність жінок сім'ї Курісів, благодійництво та праця на користь громади.

Благодійництву в Одесі та на півдні України присвячено чимало праць сучасних авторів, серед яких: В. І. Голимба, I. С. Грєбцова, О. М. Донік, Н. А. Колосова, А. І. Кочетов, С. А. Накаєва та інші. 
Мета статті - дослідження життєвого шляху Любові Іванівни Куріс, як відомої жінки та суспільного діяча.

Реформи 1860-1870-х рр. змінили масштаб і характер благодійності на півдні України. Як стверджує дослідник А. М. Савочка, в період правління Олександра II “відбулась глобальна соціокультурна трансформація системи державного піклування й суспільної доброчинності. В останній третині XIX ст. філантропія з обов'язку держави перетворилася на засіб вирішення місцевих соціальних проблем силами громади. У 1855-1881 рр. була закладена законодавча основа для стрімкого розвитку різних форм благодійності: станової та корпоративної допомоги, багатопрофільної підтримки незаможних, хворих і поранених воїнів” [22, с. 61].

На думку дослідника I. Кочергіна, серед напрямів благодійності, в яких дворянство брало участь у пореформений час, можна виділити такі: 1) пожертви на військо, допомога пораненим воїнам; 2) фінансова та матеріальна підтримка сиріт, убогих, злидарів; 3) фінансування богоугодних закладів і лікарень; 4) заснування стипендій, шкіл, підтримка освітніх закладів; 5) надання коштів на розвиток міського господарства; 6) фінансова і матеріальна підтримка бібліотек, музеїв та інших культурних закладів [11, с. 326].

Допомога армії з боку дворян була особливо активною в період збройних конфліктів. Пожертви були як колективними (благородне зібрання), так і приватними (окремі дворяни) [12, с. 393-394]. Щедрі та регулярні пожертви на армію з боку як окремих дворян, так і всього дворянства можуть бути пояснені не лише милосердям і любов’ю до ближнього. У дворянському середовищі було чимало військових, які знали, що таке війна $\mathrm{i}$ яких матеріальних сил вона вимагає. Допомога армії була також проявом вірнопідданих почуттів $\mathrm{i}$ патріотизму дворян.

Іншою була мотивація дворян при наданні підтримки лікарням, богоугодним закладам, притулкам, бідним, злидарям, сиротам. Тобто допомога хворим і нужденним сприймалася дворянами як моральний обов'язок та своєрідний податок з багатих для бідних.

Дворяни не лише жертвували різні суми на притулки, богоугодні заклади тощо, але й брали особисту участь у реалізації соціально важливих проектів. Такий вид діяльності відноситься до нематеріальної благодійності.

Особливою увагою дворянства користувалися навчальні заклади, бібліотеки, музеї, храми. Благодійність у культурній сфері має окреме визначення - меценатство. Важливою складовою просвіти завжди були бібліотеки [12, с. 398-399].

Дворянство намагалося всіляко підтримувати процес збереження культурної спадщини. Саме тому чимало дворян займалося колекціонуванням старожитностей.

Постійною підтримкою дворян користувалася церква. Матеріальна допомога розвитку церковної інфраструктури належала до традиційних видів діяльності благородного стану, тому, наприклад, будівництво храмів не було чимось унікальним для дворян. У часи, коли землі колишніх Вольностей Запорозьких роздавалися російським дворянам, більшість 3 них закладала в маєтках храми. У другій половині XIX ст. храмів будувалося менше, але дворяни продовжували допомагати церкві богослужебними книгами, іконами, коштами тощо.

Матеріальна підтримка та особиста участь у розвитку освітніх закладів у містах і сільській місцевості, бібліотек, газет, музеїв та інших об'єктів культури лежали в основі світогляду дворянства. Представники вищої верстви мали, як правило, високу освіту та рівень культури й складали еліту суспільства, що накладало певний відбиток на їх життєві установки. Моральним обов'язком дворян було збереження традицій та поширення просвіти серед народу.

Єдина сфера, де дворяни не відзначилися помітною активністю, - це громадські та творчі товариства. Благородний стан не потребував якихось окремих об'єднань, оскільки мав власну станову організацію - дворянське депутатське зібрання. Також 3 другої половини $1860-х$ років дворяни брали активну участь у роботі земських установ, тому для них не була актуальною участь у якихось інших організаціях.

Подружнє життя Любові Іванівни Куріс, уродженої Гіжицької, почалося на початку 1870х pр., коли вона одружилася з Іваном Іраклійовичем Курісом. Рід Гіжицьких походив 3 давнього польського дворянського роду, що належав до герба Гоздава і брав свій початок 3 
XV століття [20]. У Польщі існувало ще кілька родів Гіжицьких, що належали до інших гербів. Після поділів Речі Посполитої частина Гіжицьких перейшли на службу до Російської імперії й були підтверджені у спадковому дворянстві. Поступово вони стали одним із найбільш авторитетних, впливових, а також заможних землевласницьких родів на території Південної України.

Представники численного роду Гіжицьких у Херсонській губернії служили як на цивільній, так і на військовій службах, а найбільш відомими їх представниками були: Ігнатій Іванович Гіжицький - генерал-майор; Іван і Степан Олександрович Гіжицькі - предводителі дворянства Ананьївського повіту; Олександр Степанович Гіжицький - камергер, дійсний статський радник, член III i IV Державної Думи; Михайло Львович Гіжицький - Державний секретар в уряді України гетьмана П. П. Скоропадського [20]. Дослідники відзначають тісний зв'язок Гіжицьких з Одесою та наявність у них нерухомої власності на території міста.

Шляхом шлюбних взаємин Гіжицькі поріднилися з такими відомими родами, як князі Абамелікі й Голіцини, барони Веліо, дворяни Куріси, Свєчіни, Слєнєви та інші. Вже після революційних подій й залишення Одеси у січні 1920 року військами Білої армії, Гіжицькі емігрували за кордон. Їхні нащадки до цього часу проживають в різних країнах світу.

Іван Іраклійович та Любов Іванівна Куріси упродовж багатьох років демонстрували приклад сімейного взаєморозуміння, порядності, любові й гармонії серед представників аристократичних кіл краю. Любов Іванівна народилась і виросла в родинному маєтку містечка Ряснополь Одеського повіту (нині Березівський район Одеської області) [21, с. 487].

Ïї батько Іван Олександрович Гіжицький в 1850-х рр. служив в управлінні інспектора військових поселень ад’ютантом при начальнику поселенських округів генерал-майору С. Ф. Щербинському $[15,1853]$. У відставку вийшов у чині ротмістра й в подальшому присвятив себе справі сільського господарства, користуючись значним авторитетом серед поміщиків і землевласників краю. Разом з дружиною Оленою Дорофіївною вони проживали в містечку Ряснополь або в іншому своєму володінні - селі Ісаєво Ананьївського повіту (нині Миколаївський район Одеської області). Зважаючи на гарне виховання й широку ерудицію Івана Олександровича, його кілька разів обирали повітовим гласним, головою повітової управи й предводителем дворянства Ананьївського повіту [23, с. 170; 16, с. 271].

Вочевидь знайомство I. I. Куріса з родиною Гіжицьких відбулося ще в часи його служби в канцелярії предводителя дворянства Одеського повіту. Пізніше, надаючи допомогу батькам дружини, він вів господарство на 55 десятинах землі в Ряснополлі й надавав всіляку допомогу місцевим жителям. До того ж відстань між цим поселенням і Курісово-Покровським була не така вже й велика, навіть за тогочасними мірками. Впродовж 1872-1878 рр. місцева громада обирала Івана Іраклійовича старостою своєї Петропавлівської церкви [25, 1875].

Доба Івана Іраклійовича та Любові Іванівни Курісів - це часи потужних модернізаційних перетворень у державі. Реформи імператора Олександра II одна за одною відбувались в імперії, розділяючи іï існування на дореформений період та пореформений час, змінюючи традиційний уклад життя кожного з станів тогочасного суспільства. Дворянство переживало добу своєї зрілості й також було на порозі нових викликів, від здатності адекватно реагувати на які, залежало його майбутнє. 3-поміж іншого на формування світогляду дворянського стану накладала певний відбиток сформована система елітарної загальної та професійної освіти. Це неодноразово підкреслювалося в офіційній пресі пореформеного періоду, наприклад, в роботі Б. Чичеріна "Наше дворянство”: “Дворянство на противагу іншим станам прийняло європейську освіту й разом з тим засвоїло нові звичаї, традиції, спосіб життя, погляди, інтереси. Чи багато вартісного в цьому засвоєному, - це інше питання. Але можна сказати, що дворянство - єдиний створений стан в Імперії” [29, 1861].

Любов Іванівна Куріс продовжила здійснювати благочинну діяльність після матері свого чоловіка, Любові Станіславівни Куріс, яка плідно трудилася на благо Одеського жіночого благодійного товариства, аж до часів своєї смерті в 1862 р., відкрила Курісово-Покровську народну школу, усе своє життя допомагала бідним та знедоленим. 
В 1861 р. Іван Іраклійович Куріс разом з матір'ю Любов'ю Станіславівною відкрили в Курісово-Покровському народну школу, яку в подальшому повністю утримували власним коштом. Вчителі і учні були забезпечені всім необхідним: навчальними посібниками i підручниками, регулярно виписувались газети “Одеський вісник”, “Громадянин” тощо.

Поступово вона перейшла на утримання земства: частково, починаючи 31869 p., а повністю 1873 р. Земство утримувало і вчителя, і школу, яка до того часу стала зразковою. Станом на 1874 р. заняття відвідували 40 місцевих хлопчиків і двоє дівчаток [23, с. 57]. 3 1876 р. школа отримала статус народного училища.

Процесом підбору вчителів для навчального закладу також займались поміщики. Прізвища багатьох з них збереглися в різних джерелах. Так, в 1880 р. в школі працювала 24річна Катерина Андріївна Добродіїва, випускниця Оренбурзького Миколаївського інституту. Через три роки іï замінила Євдокія Іллівна Шилінг. В 1888 р. викладачами школи були Петро Акимович Ульянов і Ольга Владиславівна Ярощинська. Вчителем у 1894 р. значився Павло Михайлович Горнатенко, а вже в 1904 р. тут вчителювала Неоніла Андріївна Решетнікова [19, с. $762 ; 8$, арк. 9 зв.; 9, арк. 116; 10, арк. 32 зв.].

Любов Іванівна Куріс була захоплена ідеєю поширення народної освіти. Як попечителька Курісово-Покровського народного училища, вона сприяла завершенню в 1886 р. будівництва в містечку нового приміщення для цього навчального закладу.

Оскільки школа, а далі училище знаходились довгий час у старому малопридатному приміщенні, то Любов Іванівна прийняла рішення виправити ситуацію шляхом будівництва нової комфортабельної будівлі для розміщення навчального закладу. Вона брала участь в розробці проєкту й контролювала увесь хід виконання будівельних робіт. Училище мало статус однокласного, однак для його потреб збудували дві просторі класні кімнати з усіма зручностями, забезпечивши кожному учневі достатню площу навчального простору. В цій же будівлі розташовувалась і квартира вчителя, яка нараховувала три невеликі кімнати $[2$, c. 27,114$]$.

Влітку 1887 р., перебуваючи в гостях у родини Курісів, президент Товариства садівництва В. М. Лігін запропонував Любов Іванівні створити при училищі навчальний сад. Ідея полягала в забезпеченні можливості учням знайомитись 3 прийомами розведення плодових дерев, кущів та городини. Після обговорення ідеї, яка вочевидь сподобалась господині, він звернувся до редактора-видавця віденського журналу "Der Schulgarten" (“Шкільний сад”) пана Лангауера 3 проханням дати кілька корисних порад щодо втілення такого проекту в життя. Ніхто й не думав, що крім просвітницької діяльності, однією зі своїх місій видання ставило надавати різноманітну організаційну допомогу в організації саме таких садів. До того ж це робилося цілковито безкоштовно. Вже через місяць був готовий план навчального саду при народному училищі, згідно 3 наданими розмірами й побажаннями організаторів. Він передбачав висадити надзвичайно значну кількість різних порід дерев $\mathrm{i}$ рослин. Окремі його положення дещо скорегували, адаптувавши під місцеві реалії, і з успіхом втілили проект в життя [13, с. 81-83].

Вже на початку XX ст., після смерті I. I. Куріса, Херсонське губернське земське зібрання звернулося $з$ клопотанням про реорганізацію Курісово-Покровської земської школи. 5 грудня 1904 р. було видано наказ міністра народної освіти у якому дозволялося "перетворити згадану

школу в двокласну за своїм складом, на основі затвердженого статуту вказаної школи, 3 присвоєнням їй найменування «зразкова школа імені таємного радника I. I. Куріса" [28, с. 729].

Л. І. Куріс також брала участь у створенні ще однієї народної школи. В 1862 р. її батько Іван Олександрович Гіжицький заснував в Ряснопіллі першу місцеву школу, яку утримував своїм коштом до 1869 р. Далі вона була переведена під громадську опіку, однак зуміла проіснувати лише три роки й була закрита. В 1874 р. вже заміжня Любов Іванівна виділила 350 крб. щоб запросити вчителя й поновити навчання дітей в Ряснопіллі. 3 того часу школу відновили, а невдовзі вона отримала статус зразкової [23, с. 57].

Піклувалася Л. І. Куріс також і про школи, створені при православних храмах. В листопаді 1894 р. за рішенням святішого Синоду її нагородили Біблією “за особливі 
старання й сумління у справі благоустрою місцевих церковно-приходських шкіл” [14, с. 138]. Серед багатьох навчальних закладів Одеси, своєю увагою і турботою вона наділила жіночу гімназію С. І. Видинської і, навіть, була її попечителем впродовж 1907-1909 pp.

Проте найбільшою справою на ниві благодійництва Л. І. Куріс, була їі участь в роботі Товариства опіки над хворими дітьми міста Одеси. Цій діяльності вона присвятила майже 30 років свого життя, зробивши безліч добрих справ і вклавши у неї свою християнську любов, милосердя і незгасиму енергію.

Історія розвитку благодійництва в Одесі досліджувалася різними авторами [5; 6; 7]. За їх свідченням місто мало чималу кількість притулків, лікарень, центрів для сиріт, будинків опіки, богаділень тощо. Всебічна допомога надавалась найбіднішим прошаркам населення, хворим i нужденним. У цю справу спрямовувалась значна кількість фінансових ресурсів. Поряд 3 іншими осередками благодійності, в 1887 р. виникло Товариство благодійної допомоги хворим дітям. Ідея належала місцевій мешканці Надії Яківні Шведовій. На іiі думку, організація прийнятного санітарного догляду й амбулаторного лікування, які фактично були недоступні для бідних прошарків міста, обов'язково мала сприяти покращенню системи охорони здоров'я, рятуючи життя значної кількості дітей. Зібравши невелику групу осіб, які поділяли ії погляди на проблему здоров'я дітей з найбідніших верств суспільства, вона винесла на обговорення статут нового Товариства. Подія відбулася 4 жовтня 1887 р. в залі Одеської міської думи. На першому ж засіданні головою Товариства обрали Любов Іванівну Куріс. За словами засновників, цей вибір був вельми вдалим, оскільки "мав вирішальний вплив на швидке розширення діяльності Товариства" [30, с. 7].

Спочатку у членів Товариства були побоювання відносно фінансових можливостей організації втілювати в життя свої плани. Всі сумніви швидко зникли, оскільки знайшлося чимало бажаючих жертводавців підтримати заявлену ініціативу. Серед перших відгукнулися самі члени Товариства графи М. Д. Толстий та М. М. Толстий, а також графиня Є. Г. Толста, які внесли у фонд організації по 500 крб. кожен. Міський голова Г. Г. Маразлі передав Товариству 1000 крб. Було багато інших благодійників з різними сумами пожертв. Лише за перші 3 місяці капітал Товариства сягнув 8000 крб.

Рада Товариства зосередила свою діяльність одразу в двох напрямках. По-перше, було прийняте рішення побудувати дитячу амбулаторію на два місця для екстрених випадків надання допомоги, а по-друге, розпочати створення на одному з одеських лікувальних лиманів літньої санітарної станції, яка б уміщувала 40 дітей.

Активність Любов Іванівни Куріс на посаді голови Товариства дозволила налагодити контакти й залучити до справи багатьох відомих і впливових людей міста. Багато разів вона ініціювала проведення благодійних заходів, мета яких збір коштів для надання допомоги хворим дітям з бідних сімей. Так, серед її помічників були Лігін, барон Вітте, Люікс, Вільє, Волчанецький, Лемме та інші. Разом з ними вона влаштувала виставку виробів мистецтва й рідкісних речей. Всі бажаючі могли побачити на експозиції предмети зі сховищ багатьох одеських колекціонерів, а також Публічної бібліотеки, яка виставила свої найбільш цікаві експонати. Іван Іраклійович Куріс представив зразки старовинних меблів із власного зібрання, значну кількість рідкісних стародруків, книг з оригінальними, високохудожніми палітурками, рукописів і рідкісних історичних документів. Виставку побачило багато одеситів, а під час заходу було зібрано 783 крб. у фонд Товариства [30, с. 9]. Перелік виставлених I. І. Курісом експонатів пізніше був включений до спеціально виданого "Каталогу виставки виробів мистецтва й рідкісних речей” [14, с. 140]. Серед інших благодійних заходів відзначимо читання публічних лекцій В. Н. Лігіним, лікарем Томашевським і I. I. Мечниковим, які дозволили зібрати 1225 крб. За спектаклі в Міському театрі вдалося зібрати ще 908 крб.

Спільні зусилля дали позитивні результати. 18 травня 1888 р. на дачі Марголіна на Хаджибейському лимані відкрили перший на території Південної України санітарнолікувальний заклад для дітей. При цьому адміністрація кінної залізниці взяла на себе витрати по перевезенню 30-ти дітей разом з їх речами до місця відпочинку, а управління Сврейської лікарні надало свої купальні на лимані для безкоштовного користування дітям. Одеські аптеки 
Гаєвського, Натанзона i Центральний аптекарський склад безкоштовно постачали перев'язувальні матеріали й ліки для санітарної станції. До справи долучились й інші благодійники. В результаті лише за перше літо роботи станції, оздоровлення пройшли 62 дитини віком від 2-х до 15-и років. При цьому 52\% дітей повернулись додому цілковито здоровими, $16 \%$ - мали стійку тенденцію до одужання, а 6\% - отримали суттєві покращення на фоні своїх хвороб [30, с. 10].

За результатами роботи тимчасово організованої санітарної станції впродовж першого року роботи було прийняте рішення прискорити будівництво стаціонару. Рада Товариства всіляко прискорювала цей процес. За архітектурним проектом I. Ф. Яценка в жовтні 1889 р. на території, яку на благодійних засадах виділили граф М. Д. Толстий і І. Л. Харіпов, поблизу Хаджибейського лиману було завершене будівництво. В той самий час закінчили будівництво дитячої амбулаторії в місті на вулиці Старопортофранківській, 46. Архітектурний проект розробив Ю. М. Дмитренко. Він врахував всі побажання члена Ради Товариства лікаря О. О. Мочутковського, який повністю профінансував це будівництво в пам'ять про свою матір. В день відкриття й освячення амбулаторії 1 листопада 1889 р. він урочисто передав ключі від будівлі Раді Товариства. Й донині там знаходиться дитяча міська лікарня № 7 міста Одеси.

За більшістю добродійних справ Товариства проглядалась постать Л. І. Куріс з іï енергійністю й наполегливістю у досягненні поставленої мети. Вона й сама жертвувала чималі суми на підтримку справ Товариства. Так, коли в 1890 р. виникли труднощі через необхідність сплатити відсотки на погашення заборгованості, вона самостійно внесла суму 816 крб. власних коштів щоб вирішити проблему. В подальшому ця цифра була нею визначена як щорічна допомога на потреби Товариства.

За перші п'ять років діяльності Товариство звітувало про надання медичної допомоги 7215 дітям. Кожен місяць в теплу пору року в дитячій санітарній станції на лимані проходили оздоровлення 50 дітей. Разом з деякими знаходились матері, однак вони сплачували за харчування й проживання по 20 крб. на місяць. В 1894 р. станція отримала у своє розпорядження нові відділення: хірургічне й ізоляційне [18, с. 2]. Пізніше Товариство відкрило дитячу кухню «Крапля молока», де малозабезпечені матері мали можливість отримувати за помірну платню якісне стерилізоване молоко [3, с. 153].

До 1901 р. на санітарній станції повноцінний курс лікування пройшли понад 1500 дітей. При цьому заклад вже нараховував чотири відділення: санітарне, хірургічне, ізоляційне, очних хвороб [3, с. 95]. В 1912 р. на гроші Товариства на вулиці Старопортофранківській, 38 була збудована ще й поліклініка, яка зберіглася до нашого часу. В ній розмістили лабораторію й офіс. Саме там більшу частину часу проводила Л. І. Куріс. Після смерті чоловіка І. І. Куріса, вона поринула в роботу Товариства, що стало сенсом життя на довгі роки. На посаді голови вона працювала до 1914 р. (з невеликою перервою в 1904-1908 pp., коли їі замінила на цій посаді К. К. Вітте). Смерть сина Олександра змусила Любов Іванівну відійти від справ на посаді голови Товариства.

Після смерті чоловіка Любов Іванівна Куріс успадкувала його величезну колекцію. Однак подальше їі поповнення припинилось 3 огляду на відсутність інтересу до цієї справи. Тим не менше відносини з Одеським товариством історії та старожитностей та низкою його представників Л. І. Куріс підтримувала й навіть була прийнята у його члени. Це відбулося після того як вона подарувала музею Товариства цінні в науковому й матеріальному значеннях античні експонати 3 колекції чоловіка. Їх загальна кількість склала 21 одиницю, серед яких вази й посуд різних форм, нога статуї із бронзи, три теракотові й дві з різнокольорового скла фігури, ритон IV ст. у формі голови кабана, а також велика антична амфора із зображенням Афіни Паллади в художній оздобі. На своєму 336-му засіданні 22 травня 1901 р. члени Товариства подякували Любов Іванівні й постановили: “... за таку важливу пожертву запропонувати іiі на цьому ж засіданні обрати дійсним членом Імператорського Одеського товариства історії та старожитностей” [1, с. 42 43].

Відповідаючи Товариству, Любов Іванівна 3 усією повагою і вдячністю написала: “Приношу глибоку подяку шановному Товариству за зарахування мене до числа своїх 
співчленів. Належачи і за народженням, і за тривалим перебуванням цьому краю, долями якого особливо зайняте Товариство, я завжди цікавилася його діяльністю, тим більше, що покійний мій чоловік був одним 3 найстаріших членів Товариства, постійно жив його життям i створив для нас атмосферу, повну наукових i художніх інтересів, які зближували нас 3 провідними членами Товариства. Мої слабкі сили навряд чи дозволять мені стати діяльним його співчленом, але я завжди готова бути корисною Товариству в його важливому служінні науковим інтересам нашого Товариства" [1, с. 49].

Серед “провідних членів Товариства” Любов Іванівна мала насамперед на увазі Олексія Івановича Маркевича 3 родиною якого їх єднали давні дружні стосунки. Ця дружба продовжилась навіть після смерті глав обох сімей. Л. І. Куріс увійшла до комісії, створеної в 1903 р. після смерті О. I. Маркевича на прохання його дружини Любов Семенівни, щоб прийняти книги з бібліотеки покійного, принесені в дар бібліотеки-читальні для робітників на Молдаванці. Головою цієї комісії обрали міського голову П. О. Зеленого, а серед інших членів були граф М. М. Толстой, М. Г. Попруженко та інші відомі одесити.

В 1894 р. родина Курісів допомогла придбати для Покровської церкви новий церковний дзвін, а також футляр для дарохранильниці. В 1904 р. Любов Іванівна зробила на церкву пожертвування на суму 1474 крб. За ці кошти був побудований новий церковний дім [27, c. 52].

Родина Курісів давала пожертви не лише на користь власної Покровської церкви. Інші храми, що знаходились у сусідніх селах також отримували пожертви від них. Відомий випадок, коли у селі Слов'яно-Себка неподалік від Курісово-Покровського, в честь сходження на престол і одруження імператора Миколи II в 1894 р. вирішили капітально відремонтувати місцеву церкву святого Луки. У відповідь на звернення про пожертву Іван Іраклійович “відпустив потрібну кількість піску з берегів лиману, що йому належав” [26, с. 25-26]. Подібних випадків було чимало.

Отже, життя Любові Іванівни Куріс було тісно пов'язане з благодійництвом на користь суспільства та незахищених верств населення. Серед представників славного роду Курісів на півдні України вона здійснила немало в галузі освіти та мистецтвознавства, допомоги дітям та хворим, незабезпеченим верствам населенням. Не жаліючи власного часу та коштів представники сім’ї Курісів завжди займалися меценатством та благодійністю, Любовь Іванівна гідно продовжила їх родову справу. Розвиток та утримання освітніх закладів за власні кошти, керівництво та участь в товариствах, пожертви та меценатство слугують яскравими прикладами благочинної діяльності цієї жінки.

\section{Джерела та література:}

1. 336 заседание Императорского Одесского общества истории и древностей 22 мая 1901 года. Записки Одесского общества истории и древности. Одесса, 1902. Т. 24, ч. 5. С. 40-62.

2. Свод сведений о начальном образовании в Херсонской губернии за 1885/6 г.,. Херсон : Изд. Херсон. губ. зем управы. ; Тип. О. Д. Ходушиной, 1889. Прил. 4 л., план. 6 с.

3. Вся Одесса : адрес. и справ. книга на 1914 год. Одесса, 1914. 64, XXVIII, 188, 319, 487 с.

4. Вся Одесса : адрес. и справ. книга на 1904/5-й год. Одесса : Изд. и ред. Л. А. Лисянского, 1904. XVI, 116, $24 \mathrm{c}$.

5. Гребцова И. С. Новороссийский университет в развитии благотворительности в Одессе (вторая половина XIX - начало XX ст.). Благотворительность и меценатство в Новороссийском университете : библиогр. указ. Одесса : Астропринт, 2009. 504 с.

6. Гребцова И. С. Очерки развития женского благотворительного движения на юге Российской империи (первая половина XIX в.). Одесса : Астропринт, 2007. 279 с.

7. Гребцова И. С. Становление государственного попечительства и общественной благотворительности в Одессе в конце XVIII - 60-е гг. XIX ст. (В аспекте проблемы: центр - регион) : монографія. Одесса : Астропринт, 2006. 320 с. 
8. Державний архів Одеської області (ДАОО). Ф. 37 : Херсонська духовна консисторія. Оп. 14. Спр. 20 : Метрическая книга о рождении, браке и смерти: м. Курисово-Покровское - Покровская церковь, с. Александровка - Рождество-Богородичная церковь. 1883 г.

9. ДАОО. Ф. 37. ОП. 16. Спр. 40 : Метрические книги о рождении, браке и смерти сел: Славяно-Србка, Курисово-Покровское, церкви: Лукинская, Покровская. 1903 г. 167 арк.

10. ДАОО. Ф. 37. Оп. 16. Спр. 4 : Метрические книги о рождении, браке и смерти сел: Курисово-Покровское, Антоново-Кодинцево, Ранжево, церкви: Покровская, Варваринская, Касперо-Богородичный молитвенный дом. 1894 г.

11. Кочергін I. О. Катеринославське дворянство в умовах трансформації соціальних відносин (друга половина XIX - початок XX ст.) : дис. ... д-ра іст. наук : 07.00.01. Дніпро, 2016. 449 с.

12. Кочергін I. О. Соціальна трансформація катеринославського дворянства (друга половина XIX ст. - початок XX ст.) : монографія. Дніпропетровськ : Герда, 2015. 576 с.

13. Лигин В. Н. План для школьного сада. Труды и Отчет Одесского отдела Императорского Российского Общества садоводства за 1887 г. Одесса, 1888. С. 81-83, 1 л. план.

14. Михальченко В. А., Сивирин О. Г. Да будет правда! Одесса : Эвен, 2005. 324 с.

15. Новороссийский календарь на 1854 г. Одесса, 1853. 412, 35, V c.

16. Новороссийский календарь на 1858 год., 1857. Одесса, 469, 32, 6, VII с.

17. Одесский вестник. 1873. 25 сент. (№ 209).

18. Одесский листок. 1894. 7 июля (№ 173).

19. Памятная книга по Одесскому учебному округу, 1881 г. Одесса : Тип. П. Францова, 1881. 40, 897, 52 c.

20. Пеший А., Решетов С. Дворяне Херсонской и Бессарабской губерний Гижицкие и их потомки Памяти Любови Ивановны Курис посвящается... Вісн. Одес. іст.-краєзн. музею. 2008. Вип. 6. URL: http://www.history.odessa.ua/publication6/stat07.htm (дата звернення: 23.05.2021).

21. Россия: Полное географическое описание нашего Отечества : настольная и дорожная книга / под ред. В. П. Семенова-Тянь-Шанского. Т. 14 : Новороссия и Крым. СПб. : Изд. А. Ф. Девриена, 1910. VIII, 983 с.

22. Савочка А. Н. Благотворительность в Таврической губернии (1802-1920). Симферополь : Доля, 2012. 320 с.

23. Сборник Херсонского земства. Изд. Губерн. зем. управы. Херсон, 1876. № 4.

24. Справочная книга Одесского учебного округа. Ч. 1 : Начальные народные училища, вып. 1 : Херсонская дирекция. Одесса, 1888. 98, XVII с.

25. Херсонские епархиальные ведомости. Одесса, 1875. № 6.

26. Херсонские епархиальные ведомости. Одесса, 1894. № 2.

27. Херсонские епархиальные ведомости. Одесса, 1904. № 3, ч. 1 : офиц. С. 52.

28. Циркуляр по управлению Одесским учебным округом. Одеса, 1904. № 12 (дек.).

29. Чичерин Б. Н. Что такое теперь русское дворянство? День. 1861. № 8. Передов. ст.

30. Шведов Ф. Первое пятилетие Общества попечения о больных детях г. Одессы. 18871892. Одесса : Тип. «Одесских новостей», 1893. 44 с.

\section{References:}

1. 336 zasedanie Imperatorskogo Odesskogo obshchestva istorii i drevnostej 22 maya 1901 goda (1902) Zapiski odesskogo obshchestva istorii i drevnosti, t. 24, ch. 5, pp. 40-62. [in Russian].

2. Cvod svedenij o nachal'nom obrazovanii v Hersonskoj gubernii za 1885/6 g. (1889) Herson: Izd. Hersonskoj gubern. zemskoj upravy. Tip. O. D. Hodushinoj. [in Russian].

3. Vsya Odessa: Adresnaya i spravochnaya kniga na 1914 god (1914) Odessa. [in Russian].

4. Vsya Odessa: Adresnaya i spravochnaya kniga na 1904/5-j god (1904) Odessa: Izd. i red. L. A. Lisyanskogo. [in Russian].

5. Grebcova, I.S. (2009) Novorossijskij universitet v razvitii blagotvoritel'nosti v Odesse (vtoraya polovina XIX - nachalo XX st.): Blagotvoritel'nost' i mecenatstvo v Novorossijskom universitete: bibliograficheskij ukazatel'. Odessa: Astroprint. [in Russian]. 
6. Grebcova, I.S. (2007) Ocherki razvitiya zhenskogo blagotvoritel'nogo dvizheniya na yuge Rossijskoj imperii (pervaya polovina HIH v.). Odessa: Astroprint, 279 s. [in Russian].

7. Grebcova, I.S. (2006) Stanovlenie gosudarstvennogo popechitel'stva i obshchestvennoj blagotvoritel'nosti v Odesse v konce XVIII - 60-e gg. XIX st. (V aspekte problemy: centr - region): monografiya. Odessa: Astroprint. [in Russian].

8. Derzharhiv Odes'koï oblasti. Fund 37 (Hersons'ka duhovna konsistoriya), inventory 14, dossier 20 (Metricheskaya kniga o rozhdenii, brake i smerti: m. Kurisovo-Pokrovskoe - Pokrovskaya cerkov', s. Aleksandrovka - Rozhdestvo-Bogorodichnaya cerkov'. 1883 g.). [in Russian].

9. Derzharhiv Odes'koï oblasti. Fund 37 (9Hersons'ka duhovna konsistoriya), inventory 16, dossier 40 (Metricheskie knigi o rozhdenii, brake i smerti sel: Slavyano-Srbka, Kurisovo-Pokrovskoe, cerkvi: Lukinskaya, Pokrovskaya. 1903 g.), 167 ark. [in Russian].

10. Derzharhiv Odes'koï oblasti. F. 37 (Hersons'ka duhovna konsistoriya), inventory 16, dossier 4 (Metricheskie knigi o rozhdenii, brake i smerti sel: Kurisovo-Pokrovskoe, Antonovo-Kodincevo, Ranzhevo, cerkvi: Pokrovskaya, Varvarinskaya, Kaspero-Bogorodichnyj molitvennyj dom. 1894 g.). [in Russian].

11. Kocherhin, I.O. (2016) Katerynoslavske dvorianstvo v umovakh transformatsii sotsialnikh vidnosin (druha polovina XIX - pochatok XX st.). Doctor. Thesis. Dnipro: Natsionalnyi hirnychyi universytet. [in Ukrainian].

12. Kochergin, I.O. (2015) Social'na transformaciya katerinoslavs'kogo dvoryanstva (druga polovina HIH st. - pochatok HKH st.): monografiya. Dnipropetrovs'k: Gerda. [in Russian].

13. Ligin, V.N. (1888) Plan dlya shkol'nogo sada. Trudy i Otchet Odesskogo otdela Imperatorskogo Rossijskogo Obshchestva sadovodstva za 1887 g. Odessa, pp. 81-83, 11. plan. [in Russian].

14. Mihal'chenko, V.A., \& Sivirin, O.G. (2005) Da budet pravda! Odessa: Izdatel'stvo «Even». [in Russian].

15. Novorossijskij kalendar' na 1854 god (1853) Odessa. [in Russian].

16. Novorossijskij kalendar' na 1858 god (1857) Odessa. [in Russian].

17. Odesskij vestnik (1873). 25 Sempt. [in Russian].

18. Odesskij listok (1894). 7 July. [in Russian].

19. Pamyatnaya kniga po Odesskomu uchebnomu okrugu (1881). Odessa: Tip. P. Francova. [in Russian].

20. Peshij, A. \& Reshetov, S. (2008) Dvoryane Hersonskoj i Bessarabskoj gubernij Gizhickie i ih potomki Pamyati Lyubovi Ivanovny Kuris posvyashchaetsya... Visnik Odes'kogo Istoriko-Kracznavchogo Миzеyu, [online] issue 6. Available at: <http://www.history.odessa.ua/publication6/stat07.htm> [Accessed 23 May 2021]. [in Russian].

21. Semenova-Tyan'-SHanskogo, V.P., red. (1910) Rossiya: Polnoe geograficheskoe opisanie nashego Otechestva: Nastol'naya i dorozhnaya kniga. Sankt-Peterb: Izd. A.F. Devriena, t. 14 (Novorossiya i Krym). [in Russian].

22. Savochka, A.N. (2012) Blagotvoritel'nost'v Tavricheskoj gubernii (1802-1920). Simferopol': Dolya. [in Russian].

23. Sbornik Hersonskogo zemstva (1876). Herson: Izd. Gubern. zemskoy upravy, no. 4. [in Russian].

24. Spravochnaya kniga Odesskogo uchebnogo okruga (1888) Ch. 1 (Nachal'nye narodnye uchilishcha), issue 1 (Hersonskaya direkciya). Odessa. [in Russian].

25. Hersonskie eparhial'nye vedomosti (1875) Odessa, no. 6. [in Russian].

26. Hersonskie eparhial'nye vedomosti (1894) Odessa, no. 2. [in Russian].

27. Hersonskie eparhial'nye vedomosti (1904) Odessa, no. 3, ch. 1 (ofic.), p. 52. [in Russian].

28. Cirkulyar po upravleniyu Odesskim uchebnym okrugom (1904) no. 12, Dec. [in Russian].

29. CHicherin, B.N. (1861) CHto takoe teper' russkoe dvoryanstvo? Den', no. 8. [in Russian].

30. SHvedov, F. (1893) Pervoe pyatiletie Obshchestva popecheniya o bol'nyh detyah g. Odessy. 1887-892. Odessa: Tip. «Odesskih novostej». [in Russian]. 